\title{
The Childless Couple Efforts to Harmonize Their Marital Relationships
}

\author{
Abdul Malik Iskandar ${ }^{1}$ (D), Hasanuddin Kasim 2 (D), and Harifuddin Halim ${ }^{3, *}$ \\ ${ }^{1}$ Department of Sociology Education, Megarezky University, 90234 Makassar, Indonesia \\ 2 Department of Social Sciences, Postgraduate Program State University of Makassar, \\ 90222 Makassar, Indonesia \\ ${ }^{3}$ Department of Sociology, Bosowa University, 90231 Makassar, Indonesia \\ * Corresponding Author: athena_lord73@yahoo.com
}

\section{ARTICLE INFO}

\section{Publication Info: \\ Research Article}

How to cite:

Iskandar, A. M., Kasim, H., \&

Halim, H. (2019). The Childless

Couple Efforts to Harmonize Their

Marital Relationships. Society,

7(2), 135-149.

DOI : $10.33019 /$ society.v7i2.100

Copyright (c) 2019. Owned by Author(s), published by Society

\section{OPEN (- ACCESS CC (1) (-)}

This is an open access article.

\section{License: Attribution- \\ NonCommercial-ShareAlike (CC BY-NC-SA)}

Received: October 20, 2019;

Accepted: December 17, 2019;

Published: December 27, 2019;

\begin{abstract}
This research is to reveal (1) the childless couple's efforts to harmonize their marital relationships, (2) the efforts against stigma related to childless couples. This research is a quantitative descriptive using a survey approach. This research was conducted in East Pantar District, Alor Regency, East Nusa Tenggara (NTT) Province, Indonesia. The respondents were determined by using total sampling. Data collection techniques were carried out through questionnaires, interviews, and literature studies. Data were analyzed quantitatively using frequency tabulation and Likert Scale. The results showed that (1) The efforts to harmonize the marital relationships of childless couples are (a) internal efforts by strengthening communication and cooperation with a partner; (b) couples receive external support. (2) Efforts against stigma are (a) having positive thinking, (b) avoiding conflict, (c) avoiding sensitive talk. Based on the indicators, there were ten respondents' efforts to harmonize their marital relationships. This condition makes married couples have power and deal with the social stigma about them. The conclusion is that married couples make various efforts to harmonize their marital relationships and still hope to have children in their marriage life.
\end{abstract}




\section{Introduction}

Generally, every married couple wants offspring because children become a nuclear family maker as well as a generation successor. However, several couples find it not easy and encounter obstacles for having children. The absence of a child in the family results in the silence of a married couple in the household (Pandanwati \& Suprapti, 2012) since the presence of children in a family becomes a big hope for married couples (Fariza, 2017). Therefore, they attempt to have children among them.

Consequently, the value of children for families or parents that children are placed where parents pour love, source of family happiness, reasons for consideration of a husband and wife to cancel divorce, and also a place where parents display their various expectations. The existence of children in a family is related to the child's function of parents or their needs who will be fulfilled as a lineage connector, successor to family traditions, the outpouring of love, expectations of parents to children because children are very valuable to married couples (Masdar et al., 2017).

However, not all couples are blessed with children even for years. Socially this problem has an impact on the stigma experienced by the childless married couple. The conditions without children in married life tend to influence decisions such as divorce, polygamy, adoption of children, IVF (In Vitro Fertilization) or stay alive together.

Several studies related to the problem have been carried out such as (1) Efforts to maintain marriage of childless couples where this study explains the phenomena in general, married couples try to have children in various ways. The efforts to have children for long-lasting married couples, both modern and traditional, starting from examining the obstetrician or the shamans. The advice that is needed enthusiasm and support to strengthen partners and eliminate loneliness that has been felt for a long time. All efforts have been conducted even though this did not come to any results. The study focused on the efforts of couples to have children (Fariza, 2017). (2) Research on "Marriage Satisfaction in Childless Couples". This study explains that couples who have marital satisfaction by fulfilling aspects of marital satisfaction that bring about intimate, calm and happy relationships. Couples who have dissatisfaction with aspects of communication, spiritual, conflict resolution, economic, family and friends, nurturing, personality, and role division experience anxiety, boredom, and cause rifts. This research seems to have a focus of study on the psycho-social aspects of married couples (Mardiyan \& Kustanti, 2016). (3) Research on "Psychological problems of infertility wives in Sridadi Village, Siampog District, Brebes Regency" (Azizah, 2016). This study explains that couples experience stress with symptoms of heart rate stress becoming faster, sad, angry, afraid to meet people, mood swings, sleep patterns change, moody and not excited, depression with symptoms of fear, anxiety, anxiety, diet changes, feeling guilty, embarrassed and confused, quiet. Feeling disturbance with symptoms of sad, offended and emotional, jealous, avoiding crowds, feeling insecure, mindset disturbances that are thoughts filled with only one thing, feeling God is unfair, blaming themselves, husband/wife, and feeling imperfect. The study approach tends to be psychological.

Based on the studies above, this research focuses on the commitment and consistency of married couples to harmonize their marital relationships also to stand against the stigma about the childless couple. The reality happens to most couples in East Pantar district, Alor Regency, East Nusa Tenggara, Indonesia.

This social reality has encouraged this research to reveal about childless couples to harmonize their marital relationships against social stigma.

Copyright (C 2019. Owned by Author(s), published by Society. This is an open-access article under CC-BY-NC-SA license. 


\section{Literature Review}

\section{A. The Family Strength}

Family Strength is a dynamic condition of a family that has tenacity and resilience and contains physical and mental materials and spiritual abilities to live independently, develop themselves and their families to achieve a harmonious state in improving physical and spiritual well-being ((Undang-Undang-Undang Nomor 10 Tahun 1992 Tentang Perkembangan Penduduk dan Pembangunan Keluarga Sejahtera).

Family strength has five characteristics as a functional family that (1) An attitude of service, (2) Intimacy between husband and wife, (3) Parents who teach and train their children, (4) Husbands who are loving-leaders, and (5) Children who obey and honor their parents (Chapman, 2000).

Furthermore, it is stated that the secret of family strength or family resilience lies in the altruism spirit among family members that are trying to do something for others, doing and moving together, maintaining family relationships, creating a positive atmosphere, protecting shared dignity and celebrating life together (Pearsall, 1996).

Also, family resilience concerns the ability of an individual or family to exploit their potential to face life's challenges, including the ability to restore family functions to the way they were in the face of challenges and crises (the National Network for Family Resilience, 1995).

Family strength or family resilience also concerns the ability of families to manage the problems they face based on their resources to meet the needs of their families; Measured using a systems approach that includes input components (physical and non- physical resources), processes (family management, family problems, coping mechanisms) and outputs (meeting physical and psychosocial needs). So the family has: (a) Physical endurance if the fulfillment of food, clothing, housing, education and health needs (indicator: per capita income exceeds the minimum physical needs) and free from economic problems (indicator: free from economic problems). (b) Social resilience if oriented towards religious values, communication takes place effectively, high family commitment (a division of roles, support for advancing and family time together, fostering social relations and problem-solving mechanisms. (c) Psychological resilience of the family if the family can cope with non-physical problems, positive emotional control, positive self-concept (including expectations and satisfaction) and husband's care for his wife (Sunarti, 2001).

It is a holistic concept that assembles the flow of thought of a system, starting from the quality of resource resilience, coping and appraisal strategies. Family Resilience is a dynamic process within the family to make positive adaptations to external and internal hazards (McCubbin \& Thompson, 1987).

Otto mentioned the components of family strengths include: (a) Family integrity, loyalty, and cooperation in the family, (b) Strong emotional ties, (c) Mutual respect among family members, (d) Flexibility in carrying out family roles, (e) The ability of care and care in child growth and development, (f) Effective communication, (g) The ability to listen sensitively, (h) Meeting the spiritual needs of the family, (i) Ability to maintain relationships with the environment outside the family, (j) Ability to ask for help when needed, (k) Ability to develop through experience, (l) Love and understand, (m) Spiritual commitment, (n) Active participation in the community (McCubbin \& Thompson, 1987).

\section{B. Social Stigma}

Erving Goffman stated that Stigma is a concept of symbolic interactionism where the condition of a person or individual is excluded, excluded or disqualified from social acceptance. 
Whereas sociologically, stigma arises from the process of interaction involving the community until the individual receives stigma from the community. A stigma is a form of social reaction from the community. Goffman mentions two categories of individuals who have certain characteristics that have the potential to be excluded, excluded, disqualified or rejected by society. Goffman's focus is the interaction between stigmatized individuals and the social control agents that create the stigma. Two types of individuals who are stigmatized according to Goffman include: (1) Discredited stigma, is a condition in which the differences of an individual have been known and proven significantly. Their shortcomings can be seen easily. (2) Discreditable stigma is an individual who gets the assumption that the stigma that exists in him is not directly given by the community because the differences they have are not immediately understood or known to the community. Stigma is accepted by families without children are a process of interaction with the community where families without children are considered as families that fail because it does not produce offspring or inheritors. The stigma given to families without children by the community is in the form of discredited stigma. The difference between families without children and other normal families can be seen clearly with the absence of children in the household. So that married couples who do not have children tend to be underestimated, humiliated or even get prejudice such as infertility, karma or disease. The stigma of a childless family as a family that fails to make one or both of them causes the husband and wife to experience discomfort from the absence of the child in their household, especially if the marriage has lasted long enough. Therefore, the stigma received by a husband and wife without children will affect interactions with the social environment and the social role played by married couples who do not have children.

\section{Social Harmony}

Social harmony is a state of balance in social life. Two mutually sustainable words, defining the ideal state desired by society. Harmony will be realized if there is an attitude of mutual respect and love between family members or communities who live together and have a variety of differences. The term illustrates the high ideals of social life. Social harmony will never be achieved if conflicts and tensions do not occur frequently within the community members.

In the same way; social harmony can also be understood as a condition where individuals live in harmony to reach development in their society (Mulya, 2015). Therefore, the social harmony that has been realized in the community is always marked by solidarity in various forms such as cooperation (known as Gotong Royong) and solidarity.

In this study, social harmonization is a safe and peaceful living condition that is achieved by married couples without children among them. A married couple continues living as a peaceful family in a negative public opinion of them.

\section{Research Methodology}

This study focuses on efforts to maintain family harmony carried out by married couples without children both biologically and adopted children at the time of this research conducted. There were 18 respondents in Toang Village, East Pantar District, Alor Regency, East Nusa Tenggara, Indonesia. This number is classified as the highest compared to other villages in the same sub-district (Anonymous, 2017). They were determined as respondents by using the Total Sampling technique. Data collection used questionnaire techniques, interview techniques, and literature review. The questionnaire technique use was intended to generate general data related to indicators in the strength of their marital life harmony. There were 10 questions in the questionnaire. Also, structured interview techniques used to generate deeper information about

Copyright (C 2019. Owned by Author(s), published by Society. This is an open-access article under CC-BY-NC-SA license. 
some questions in the questionnaire, so this interview serves as supporting data for the questionnaire. The literature review technique was used to strengthen the theoretical assumptions related to the focus of this study. Data analysis used frequency tabulation with a Likert Scale measurement technique (Sugiyono, 1998). At the indicator level, the measurement used a 5-point Likert Scale with different descriptions.

\section{Results and Discussion}

A. Respondent Characteristics

1) Ages

There were 18 respondents with various ages as described below:

Figure 1

Distribution of Respondents by Age

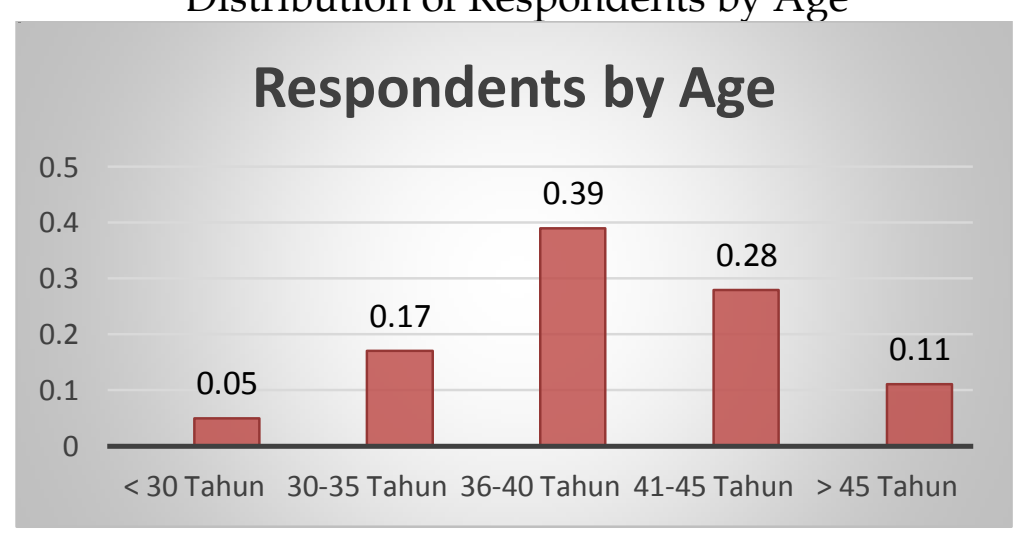

Source: (Primary Data, 2018)

From the figure 1 above, the number of respondents age of $<30$ years old were 5\% (1 respondent), the respondents between 30-35 years old were 17\% (3 respondents), the respondents between 36-40 years old were 39\% (7 respondents), the respondents between $41-45$ years old were $28 \%$ (5 respondents), and the rest of respondents $>45$ years old were $11 \%(2$ respondents).

\section{2) Education}

Out of 18 respondents were different from the level of education. The differences as in figure 2 below:

Figure 2

Distribution of Respondents by Education

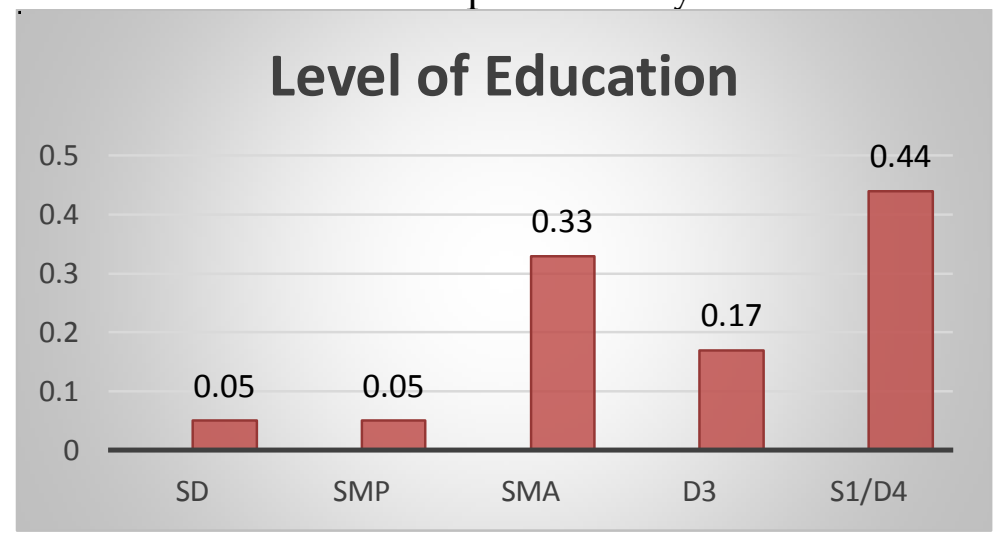

Source: (Primary Data, 2018)

Copyright (C 2019. Owned by Author(s), published by Society. This is an open-access article under CC-BY-NC-SA license. 
From Figure 2 above, the level of education of respondents were differences. 5.5\% (1 respondent) of respondents attended Primary School (SD), 5.5\% (1 respondent) attended Junior High School (SMP), 33 \% (6 respondents) of respondent attended Senior High School (SMA), 17 $\%$ (3 respondents) of respondents attended Three Years College Program (D3), and the rest were 39\% (7 respondents) of respondents attended university (Bachelor Degree)

\section{3) Religion}

Overall, 18 respondents of this study were homogenous religion as shown in figure 3:

Figure 3

Distribution of Respondents by Religion

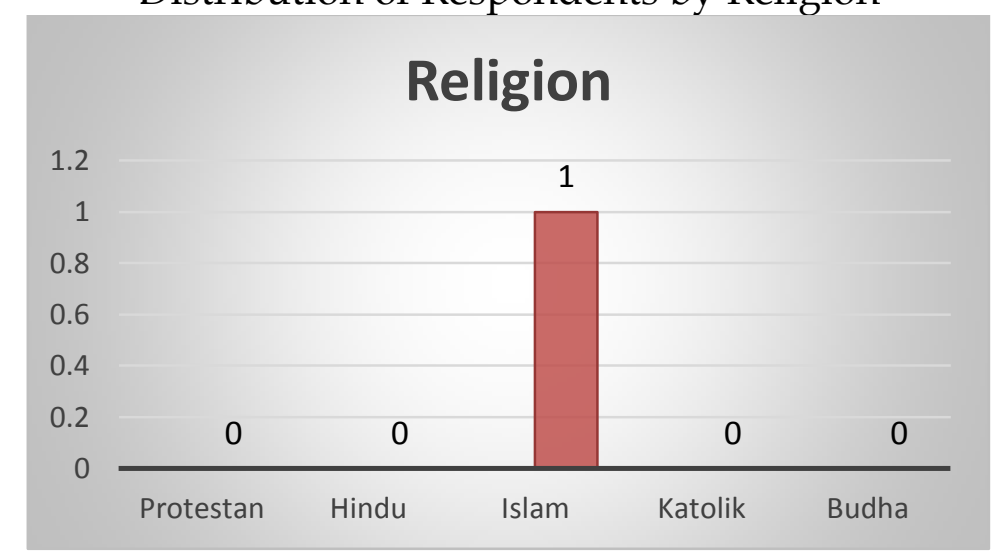

Source: (Primary Data, 2018)

From Figure 3 above, the overall of 18 respondents was Muslim (100\%).

\section{4) Livelihoods}

Livelihoods are important to meet their daily needs. This indicator was to map the type of respondent's livelihoods.

Figure 4

Distribution of Respondents by livelihoods

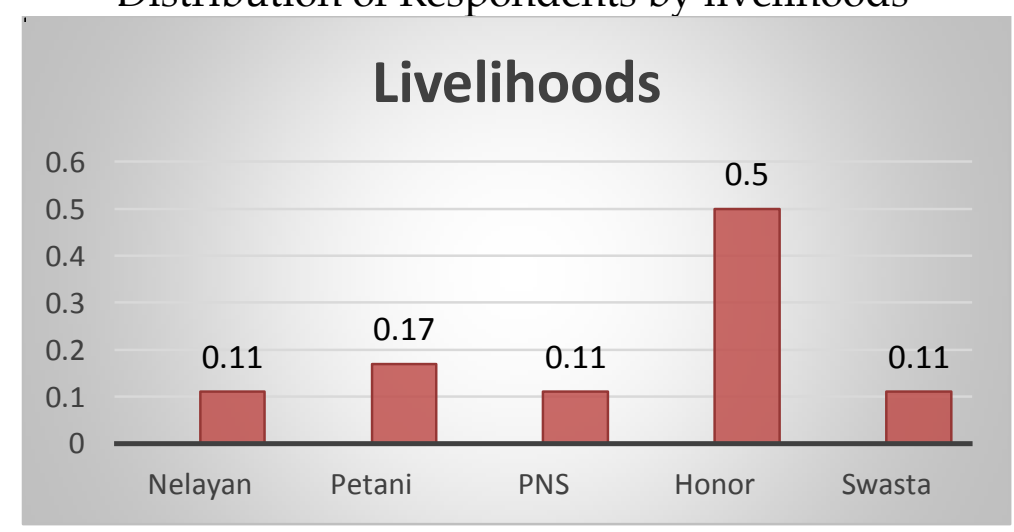

Source: (Primary Data, 2018)

From Figure 4 above, the respondents' livelihood was varied. 50\% (9 respondents) were non-permanent employee in Government service (known as Honorer), $11 \%$ (2 respondents) of respondents were private-sector employees, $11 \%$ (2 respondents) of respondents were 
fishermen, 11\% (2 respondents) were civil servants (PNS), and 17\% (3 respondents) of respondents were farmers.

\section{B. Childless Couple Efforts to Harmonize Their Marital Relationships Internal Efforts 1) Internal Efforts}

All respondents stated that it is an ideal life for every couple to live in Harmonious family continuity. The descriptions as shown in table 1 :

\section{Table 1}

Childless Couple Efforts to Harmonize Their Marital Relationships

\begin{tabular}{|c|c|c|}
\hline No. & Indicators & Likert Scale and measurement \\
\hline 1. & Loyalty in a relationship & $\begin{array}{l}\text { (1) never } 0 \% \text {, } \\
\text { (2) rarely } 0 \% \text {, } \\
\text { (3) sometimes } 13,70 \% \text {, } \\
\text { (4) often } 24,63 \% \text {, } \\
\text { (5) always } 61,67 \% .\end{array}$ \\
\hline 2. & Having emotional intimacy connection to partner & $\begin{array}{l}\text { (1) never } 0 \% \text {, } \\
\text { (2) rarely } 0 \% \text {, } \\
\text { (3) sometimes } 11,46 \% \text {, } \\
\text { (4) often } 13,32 \% \text {, } \\
\text { (5) always } 75,40 \% \text {. }\end{array}$ \\
\hline 3. & Respecting each other & $\begin{array}{l}\text { (1) never } 0 \% \text {, } \\
\text { (2) rarely } 0 \% \text {, } \\
\text { (3) sometimes } 14,75 \% \text {, } \\
\text { (4) often } 16,40 \% \text {, } \\
\text { (5) always } 68,85 \% \text {. }\end{array}$ \\
\hline 4. & Flexibility in relationships & $\begin{array}{l}\text { (1) never } 0 \% \text {, } \\
\text { (2) rarely } 0 \% \text {, } \\
\text { (3) sometimes } 6,55 \% \text {, } \\
\text { (4) often } 22,95 \% \text {, } \\
\text { (5) always } 70,50 \%\end{array}$ \\
\hline 5. & Communication in relationships & $\begin{array}{l}\text { (1) never } 0 \% \text {, } \\
\text { (2) rarely } 0 \% \text {, } \\
\text { (3) sometimes } 0 \% \text {, } \\
\text { (4) often } 16,40 \% \text {, } \\
\text { (5) always } 83,60 \% .\end{array}$ \\
\hline 6. & Listen to partners intentionaly & $\begin{array}{l}\text { (1) never } 0 \% \text {, } \\
\text { (2) rarely } 0 \%, \\
\text { (3) sometimes } 0 \%, \\
\text { (4) often } 65,80 \%, \\
\text { (5) never } 54,20 \%\end{array}$ \\
\hline 7. & Fulfilling partners spiritual needs & $\begin{array}{l}\text { (1) never } 0 \% \text {, } \\
\text { (2) rarely } 0 \% \text {, } \\
\text { (3) sometimes } 0 \% \text {, } \\
\text { (4) often } 50,82 \% \text {, } \\
\text { (5) always } 49,18 \% \text {. }\end{array}$ \\
\hline
\end{tabular}




\begin{tabular}{|c|c|c|}
\hline No. & Indicators & Likert Scale and measurement \\
\hline 8. & Building relationships with partner relatives & $\begin{array}{l}\text { (1) never } 0 \% \text {, } \\
\text { (2) rarely } 0 \% \text {, } \\
\text { (3) sometimes } 0 \% \text {, } \\
\text { (4) often } 55,72 \% \text {, } \\
\text { (5) always } 44,28 \% \text {. }\end{array}$ \\
\hline 9. & Loving and understanding partners & $\begin{array}{l}\text { (1) never } 0 \% \text {, } \\
\text { (2) rarely } 0 \% \text {, } \\
\text { (3) sometimes } 0 \% \text {, } \\
\text { (4) often } 20,13 \% \text {, } \\
\text { (5) always } 79,87 \% \text {. }\end{array}$ \\
\hline 10 . & Participating together in society & $\begin{array}{l}\text { (1) never } 0 \% \text {, } \\
\text { (2) rarely } 0 \% \text {, } \\
\text { (3) sometimes } 13,70 \% \text {, } \\
\text { (4) often } 21,53 \% \text {, } \\
\text { (5) always } 64,77 \% \text {. }\end{array}$ \\
\hline
\end{tabular}

\section{Source: (Primary Data, 2018)}

According to Table 1 above, it can be illustrated that out of 10 indicators which represent the efforts of a married couple to maintain a family. The indicator is based on the questions outlined as follows;

1) Loyalty to each other, more than three quarters $(86,30 \%)$ of respondents who are loyal to the partners and the remaining $13.70 \%$ sometimes loyal.

2) Having a strong emotional tie with a partner, almost all have it (88, $72 \%)$, and only $11.46 \%$ sometimes have it.

3) Mutual respect, about $85.25 \%$ do it and the rest sometimes.

4) Flexibility with a partner is important in the family. This is done by almost all respondents $(73.45 \%)$ and only $6.55 \%$ which is sometimes flexible.

5) The above flexibility is very much related to the item 'Communication with a partner'. This is a priority because all respondents do it in the details 'always' (16.40\%), and 'often' (83, $60 \%)$.

6) Another thing related to communication is 'listen to partner intentionally.' The results of the questionnaire presented that all respondents listened to their partners intentionally (100\%).

7) Meeting the spiritual needs of the couple implies inner satisfaction with the couple. It is recognized by all respondents that they meet their needs with each other $(100 \%)$.

8) Maintaining relationships with each other's family environment, each partner does it fully $(100 \%)$ as a form of support for their marriage.

9) Loving and understanding a partner is a must in marriage. All respondents admitted that they loved each other $(100 \%)$ until the study took place.

10) Participating in society with a partner is an indicator of family resilience. Related to this, more than three quarters $(86.30 \%)$ of respondents were indeed involved in social activities with their partners and the rest were involved only once depending on the availability of each time. 
From the whole questionnaire items above, the outcome of the respondents' efforts to harmonize their marital relationships is as follows;

\section{Figure 5}

The Outcome of Respondents on Efforts to Harmonize Their Marital Relationships

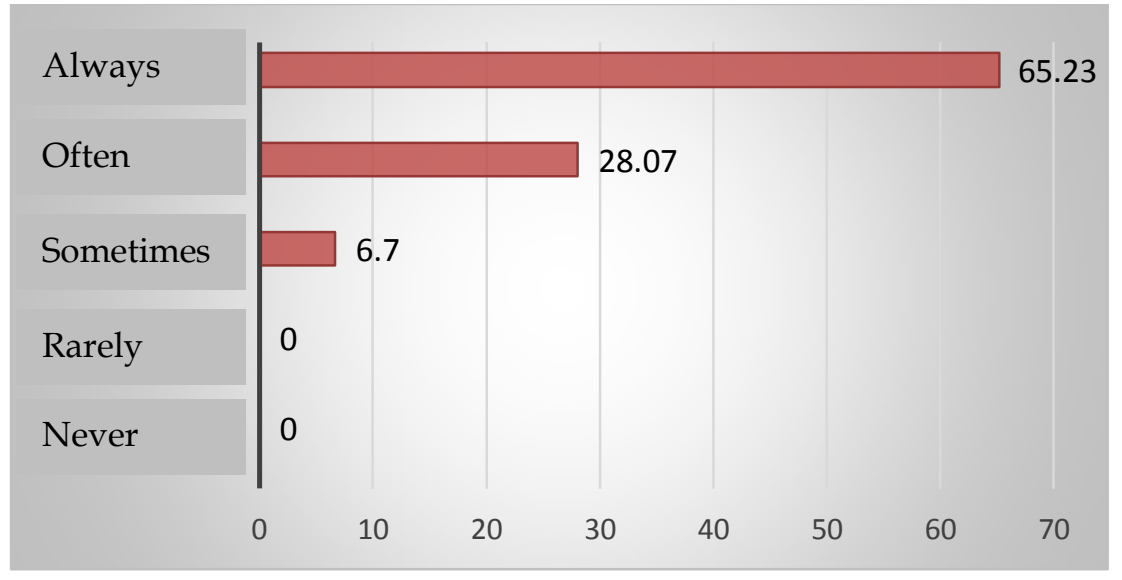

Source: (Primary Data, 2018)

From Figure 5 above, almost all (92.3\%) respondents who try to harmonize their marital relationships even though they do not have children. The rest $(6.7 \%)$ in the 'sometimes' category does not mean not doing, but rather in certain aspects which conditionally influence their decisions.

To deepen the results of the questionnaire above, researchers also conducted in-depth interviews with 5 selected respondents based on the long-lasting marriage of 10 years and over.

Respondents who have been married for the last 10 years but still have no children, feel anxiety and loneliness but remain optimistic. Respondents stated that although they were anxious because there were no children and were afraid of being separated, they still lived it hopefully while strengthening their ties to remain calm. (Interview HS, 35 years old, on July 19 2018).

Another optimistic attitude was also expressed by married couples Q and F (32 years and 33 years) stated:

"Since we had been married, we were expecting a baby among us. But, the expectation is gone. We never had a baby until today. Maybe God has not blessed us, we are always expecting and praying for a baby, we always respect each other even we realize how important child as our offspring" (Interview on July 16, 2018).

According to the description of the interview above, it reveals that an optimistic attitude towards various things is strength to fight the pessimism due to the absence of children. This situation is also found in the results of research on future optimism in married couples who have not been blessed with children. This optimism is caused by religious belief (Sa'adah, 2018).

Another cause is satisfaction with each other. This is also explained in the findings of a research that although they do not have offspring, each partner is to provide a sense of comfort and satisfaction then the household must survive (Mardiyan \& Kustanti, 2016). 
The husband and wife above is an image of reality that reveals that the existence of children is indeed important, but far more important is the harmonization of the family with a partner. That is, they do not question the presence or absence of children in their midst. This situation shows that the couple made continuous renewal of the consensus that they had made together before marriage (Hadawiah, 2017).

In contrast to other families who make it a source of conflict so they are less harmonious (Fincham \& Beach, 1999). This was confirmed by Sprey that the conflict with the partner was caused by incompatible interests (Laswell \& Laswell, 1987).

Figure 6

One of the Respondents (A Childless Couple)

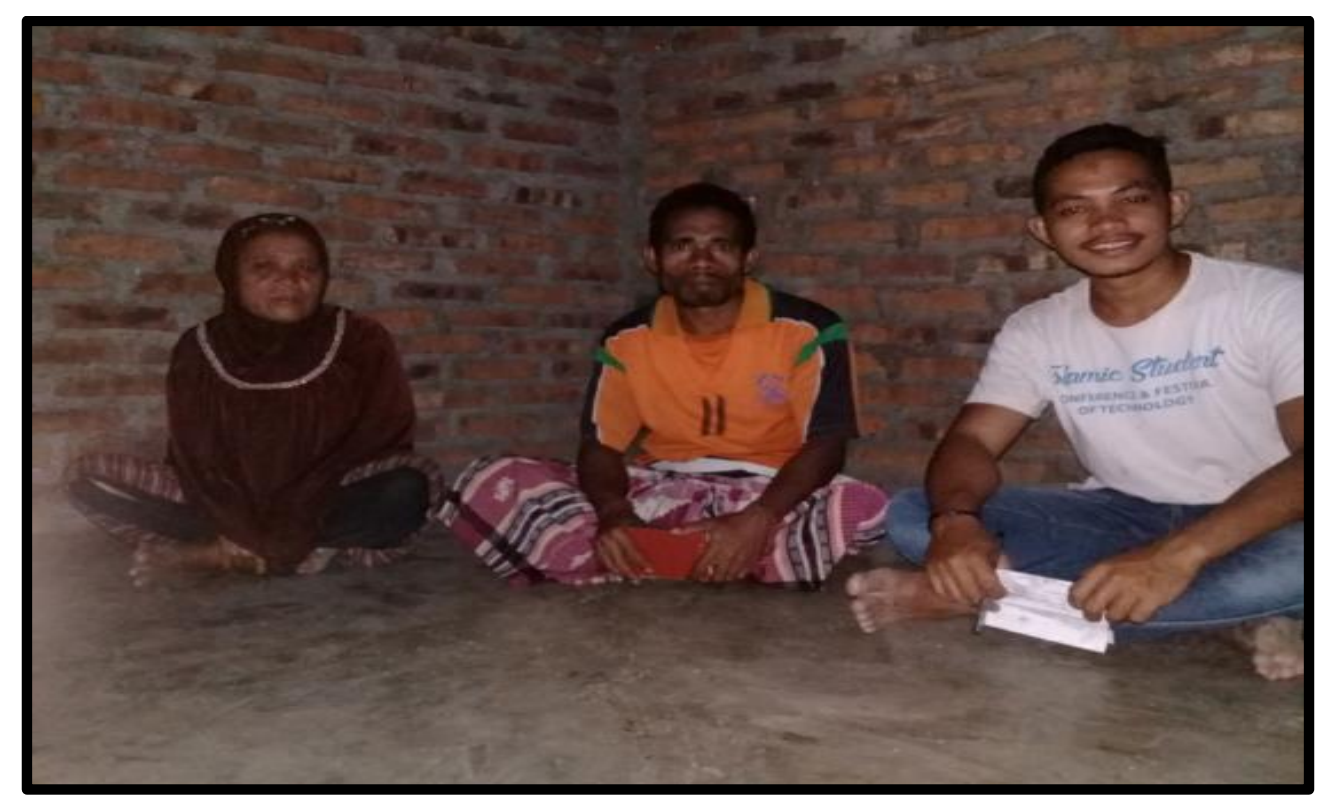

Source: (Kasim, 2018)

Theoretically, respondent efforts (couples without children) to harmonize their marital relationships as described by McCubbin and Thompson have two sides; strengthening inward with a partner and strengthening outward, it is the social environment. The reinforcement is more representative of strengthening interpersonal loyalty commitments for them. Strengthening out with a partner is more 'show on' on the loyalty of the couple that they show to neighbors or the surrounding community. If these two aspects function in parallel then family strength as a 'family resilience' can be realized. The impact then is family harmonization and social harmony.

\section{2) External Efforts}

Additionally, the internal efforts as described above, external support also strengthen the existence of a partner. The referred external support often comes from the closest people such as parents, siblings, and friends. They are the spirit of a couple to survive even though not all the closest people provide support. Even, they considered separating and finding a new partner.

In this study, the couple interviewed received support from relatives and parents to stay together with their partners. When there is a sense of boredom in a lonely situation due to the absence of children, then they appear and are present to provide support. This is following the

Copyright (C) 2019. Owned by Author(s), published by Society. This is an open-access article under CC-BY-NC-SA license. https://doi.org/10.33019/society.v7i2.100

144 
results of the interview with one of the respondents in the pair R and R (35 years and 37 years), stating:

"The one who understands my situation is my husband and my uncle. Both of them always remind me to stop blaming God. My husband also advises me to live in harmony with each other." (Interview on July 20, 2018).

Other support also comes from friends. This is for example as told by the HRF and RZD couple (47 years and 45 years) who revealed:

"We have an old friend and he often supports us to stay together forever. She also has been long-lasting married but at last, he had a baby. He always tried and prayed. His patience and his experience motivated us."

Based on the above interview description it can be said that support is very important and very helpful. In the context of this research, friends and family are the components that do it most often. In many cases, this aspect did not happen much.

\section{Childless Couples Faced Social Stigma \\ 1) Stigma Forms \\ a. Infertility}

Infertility is often noted or stigmatized in couples who have been married for several years but have not yet had a child. This stigma is socially unfounded because couples who do not have children are not only caused by infertility issues but there are other personal factors.

Regarding infertility as a social stigma, there is an impression that this term tends to have a negative meaning. Couples are given the stigma of 'infertility' socially brings the impression that the couple is not good and indicates that there is something bad attached to the infertile couple. This is as revealed by the pairs of respondents CL (36 years) and RHN (32 years) that:

"The word mandul (infertility) means negative and the word is not interested in ears.

We never heard the word pointed directly to us. But we sometimes hear it from others to point another. The word hurts us." (Interview on July 21, 2018).

Other couples with different processes so that they do not have offspring do not have the same sensitivity as the pair above. The reason is not due to infertility but weak content. Previously the couple had been pregnant twice but only lasted 3-4 months after having a miscarriage. The couple revealed the following:

"We were happy for 4 months because my wife got pregnant twice. But I don't know why the embryo died and miscarriage happened. It is we don't hurt when someone pronounces "infertility" in front of us because we are different from others. My wife had been pregnant so we are not infertility." (Interview on July 23, 2018).

Based on the description of the interview above, it can be stated that the stigma of 'infertility' is a label that is 'always' attached to people who do not have offspring. This stigma is not all true. But in status, stigma only arises in certain situations. Respondents also reacted naturally because it was part of the process they had to go through so they were just patient, accepted it gracefully. 


\section{b. Failed Family}

The stigma as 'family fails' is also widely accepted by respondents. This is certainly in the sense that they 'fail' to have children. However, as a stigma, this has a psychological impact and seems negative.

Respondents as 'failed families 'feel the psychological pressure both internally and externally. The DRW couple (45 years) and KMS (44 years) tell:

"Hearing people talk about the failed family pointed to us is hurt. But we always pray and hope we have children someday."(Interview on July 16, 2018).

Other respondents HRY (46 years) and SRN (44 years) also told the same:

"People always talk badly on us because of childless. But we just accept it and patience. We believe we will have children someday." (Interview on July 24, 2018).

Based on the description of the interview above, it is implied by the meaning of the respondents that stigma is a necessity that must exist. Therefore, stigma cannot be avoided, but attitude is important in responding.

\section{2) Handling the Stigma \\ a. Positive Thinking}

Respondents who do not have children experience psychological pressure. They are urged to provide evidence of the results of their marriage. Responding to those urges, they learn to control emotions. In this regard, the pairs of respondents $Q$ and $F$ (32 years and 33 years) stated:

"We always get pressure from the family to always check with the midwife about it and until repeatedly urged so that often they are labeled an infertile partner so that they feel bored with family opinions and sometimes even a small fight with the family." (Interview July 16, 2018).

Disputes with family members, such as with parents, in-laws, especially husbands are very difficult to avoid. One way to anticipate this is to discuss issues openly and make an agreement with her husband on how to deal with family pressures. And do not give negative reactions to anything related to the problem of having children. Give a positive response when parents or relatives, or even neighbors, constantly asking questions about children, and see it as a form of attention from them. In essence, respondents always respond to these problems with positive thinking.

\section{b. Avoiding Conflict}

Parents or families do not judge their married children even though do not have children. They still provide sincere support, not insistence and stigma. They avoid words that compare with other couples because doing so can offend them. According to the pair R and R (35 years and 37 years), it states that:

"The pressure from the family is very difficult to avoid even by constantly asking why we are not like other couples or because you can no longer have children?" (Interview on July 20, 2018). 
It is also as I and S (32 years old and 34 years old), stated that:

"Somewhat difficult to stem the hopes of their parents who always ask when giving grandchildren to the grandmother, this makes them feel there is a burden in their partner's life." (Interview on July 23, 2018).

A childless married couple is not only stigmatized by the family, but also from the community who always question the couple, which leads to self-isolation. Feeling isolated or feeling isolated is a condition that often occurs to married couples without children. This condition is expressed as feelings of isolation in their environment.

This is as according to pairs $Q$ and $F$ (32 years old and 33 years old) stated:

"They feel inferior when attending family events or gatherings or activities outside the home, such as a family gathering or school reunion because it will make them feel isolated because friends always talk about children's problems and ask them about it." (Interview on July 16, 2018).

Based on the results of the interview above, it can be explained that avoiding conflict with family, friends, or neighbors is one of the efforts made by respondents. Therefore, when they meet or gather they are quiet or divert a lot of conversation when dealing with children's problems.

\section{c. Avoiding Sensitive Talk}

Couples without children often depend on one another for social support, because they do not discuss infertility problems with others, but only with people they trust can provide solutions or help with information. This is as stated by the AHM (44 years) and ZNB (44 years) respondent pairs that they tend to be closed and secretive in revealing their health condition to others, except those they know such as doctors or shamans ("smart people"). Therefore, they are more likely to avoid sensitive talks when meeting family or anyone (Interview on August 2, 2018).

Related to the description above, there are impacts that they can experience when responding to talk about their condition, such as sadness, jealousy or envy, anxiety, isolation, and anger. This condition then caused a shock in their family. However, this did not damage the household of a married couple without children.

In dealing with the problems described above, the couple reacts with one of four ways to overcome family problems, namely by avoiding conflict, succumbing, discussion, and competence (Fitzpatrick \& Badzinski, 1994). The thing most often done in avoiding conflict by respondents is to change the subject, and discuss (Dewi \& Basti, 2008)

\section{Conclusion}

Marital couples without children face many challenges, one of which is to maintain conditions of social harmony. There are various efforts to maintain their family or spouse both internal and external efforts. Internally they improve the quality of communication with their partners and externally receive support from family and friends who understand their condition.

Additionally, they also face negative stigma as infertile families and failed families. They deal with it by avoiding conflict, more discussion, and consultation. 


\section{Acknowledgement}

We want to say our sincere gratitude to the Head of District East Pantar East Nusa Tenggara (NTT) Province, Indonesia, the respondents, and others who assisted our research. We also say our gratitude to the Megarezky University for permitting us to conduct this research.

\section{References}

Anonymous. (2017). Profil Penduduk Desa Toang Kecamatan Pantar Timur Kabupaten Alor. Desa Toang: Kantor Desa Toang.

Arianto. (2018). Struktur Kepemilikan, Profitabilitas, Pertumbuhan Aktiva, dan Ukuran Perusahaan Terhadap Struktur Modal Pada Perusahaan Manufaktur. Malang: Universitas Negeri Malang.

Azizah, N. (2016). Problem Psikologis Istri Yang Belum Dikaruniai Keturunan Di Desa Sridadi Kecamatan Sirampog Kabupaten Brebes. Tesis. Purwokerto, Jawa Tengah, Purwokerto: IAIN Purwokerto.

Badan Pengembangan Bahasa dan Perbukuan. (2019, October 19). Retrieved from https://kbbi.kemdikbud.go.id/entri/: https://kbbi.kemdikbud.go.id/entri/konsistensi.

Chapman, G. (2000). Five signs of a functional family (Lima tanda keluarga yang mantap). Batam: Interaksara.

Dewi, E. M., \& Basti. (2008). Konflik Perkawinan Dan Model Penyelesaian Konflik. Jurnal Psikologi, Vol 2 No.1 Desember 2008, 42-52.

Fariza, A. M. (2017). Upaya Pasangan Yang Tidak Memiliki Anak Untuk Mempertahankan Perkawinan. Jurnal Ilmiah Mahasiswa FISIP Unsyiah, 1127-1146.

Fincham, F. D., \& Beach, S. R. (1999). Conflict in marriage: implications for working with couples. Annual Review Psychology, 47-77.

Fitzpatrick, M. A., \& Badzinski, D. M. (1994). All in The Family: Interpersonal Communication in Kin Relationship. In T. G. Peter M. Kellett. Handbook of Interpersonal Communication (pp. 71-726). California: Thousand Oaks.

Ghozali, A. R. (2003). Fiqih Munakahat. Jakarta: Prenada Media.

Hadawiah, H. (2017). Pola Komunikasi Pasangan Suami Istri Beda Budaya Di Makassar. AlMunzir, 10(2), 228-245.

Isnaeni, M. (2016). Hukum Perkawinan Indonesia. Bandung: Refika Aditama.

Laswell, M. L., \& Laswell, M. (1987). Marriage and the family. California USA: Woodsworth Inc. Mardiyan, R., \& Kustanti, E. R. (2017). Kepuasan pernikahan pada pasangan yang belum memiliki keturunan. Empati, 5(3), 558-565.

Masdar, M., Halim, H., Zainuddin, R., Rosmawati, Roslinawati, Iskandar, A. M., \& Amir, A. (2017). Developing Islamic Family as Religious Symbol Reinforcement. In N. Susan, Democracy And Social Transformation: (Pp. 62-64). Surabaya: APSSI Indonesia.

McCubbin, H., \& Thompson, A. (1987). Family Assessment Inventories for Research and Practices. Wisconsin: University of Wisconsin Madison.

Mulya, W. N. (2015, Desember 18). Perbedaan Kesetaraan, dan Harmonisasi Sosial. Retrieved from blog.unnes.ac.id/: blog.unnes.ac.id/warungilmu/.

Pandanwati, K. S., \& Suprapti, V. (2012). Resiliensi Keluarga Pada Pasangan Dewasa Madya Yang Tidak Memilik Anak. Jurnal Psikologi Pendidikan dan Perkembangan, 1(3), 1-8. 
Pearsall, P. (1996). Rahasia Kekuatan Keluarga Membangkitkan Kekuatan Hidup Keluarga Untuk Memperkokoh, Membangkitkan Kembali, dan Menyembuhkan. Jakarta: Pustaka Delaptarasa.

Sa'adah, N. (2018). Optimisme Masa Depan Pada Pasangan Suami Istri Yang Belum Dikaruniai Anak. 15: Program Studi Psikologi Fakultas Psikologi Universitas Muhammadiyah Surakarta.

Sugiyono. (1998). Metode Penelitian Administrasi. Yogyakarta: Andi Press.

Sunarti, E. (2001). Ketahanan Keluarga. Bogor: Institut Pertanian Bogor Press.

\section{About the Authors}

1. Abdul Malik Iskandar, obtained his Doctoral Degree (Ph.D.) from State University of Makassar, Indonesia, in 2015. The author is an Assistan Professor at Department of Sociology Education, Faculty of Teacher Training and Education, Megarezky University, Makassar, Indonesia. E-Mail: abdul.malikiskandar@yahoo.com.

2. Hasanuddin Kasim, is a graduate student of Department of Social Sciences, Specialization in Sociology Education, State University of Makassar, Indonesia. E-Mail: hasanudinkasim16@gmail.com.

3. Harifuddin Halim, obtained his Doctoral Degree (Ph.D.) from State University of Makassar, Indonesia, in 2015. The author is an Assistan Professor at Department of Sociology, Faculty of Social and Political Sciences, Bosowa University, Makassar, Indonesia. E-Mail: athena_lord73@yahoo.com. 